\title{
Supplementation of Mineral Nutrients through Foliar Spray-A Review
}

\author{
M. Rajasekar ${ }^{1}$, D. Udhaya Nandhini ${ }^{2 *}$ and S. Suganthi ${ }^{3}$ \\ ${ }^{1}$ Precision farming Development Centre, Agriculture Engineering College, India \\ ${ }^{2}$ Department of Sustainable Organic Agriculture, Tamil Nadu Agricultural University, \\ Coimbatore-641 003, India \\ ${ }^{3}$ Department of Spices, Plantation, Medicinal and Aromatic Crops, Tamil Nadu Agricultural \\ University, Coimbatore-641 003, India
}

*Corresponding author

Ke ywords

Foliar fertilization, stomata, leaf cuticle, plant hormones and stimulants.

Article Info

Accepted:

20 February 2017

Available Online:

10 March 2017
Foliar fertilization is nutrition through leaves, is a very efficient technique of supplementary fertilization. Foliar nutrition is very important because foliar nutrients facilitate easy and quick consumption of nutrients by penetrating the stomata or leaf cuticle and enters the cells. Foliar fertilization is used as a means of supplying supplemental doses of macro and micro-nutrients, plant hormones, stimulants, and other beneficial substances. It is determined that during crop growth supplementary foliar fertilization increase plants mineral status and improve crop yields. Keeping these facts in view, the literatures on foliar application of plant mineral nutrients on crops are reviewed in this paper to indicate future benefits of foliar nutrient spray investigations and their importance for agronomic science and practice.

\section{Introduction}

Foliar application of nutrients, conceptually over 100 years old, is gaining importance in many crops. Foliar nutrition is recognized as an important method of fertilization, since foliar nutrients usually penetrate the leaf cuticle or stomata and enter the cells facilitating easy and rapid utilization of nutrients. Foliar sprays are used for three main purposes. They are (i) to maintain optimum nutrition of a particular nutrient, (ii) to give a crop nutritional boost at a critical junctures of different phenophases and (iii) to correct deficiency disorders (Wittwer and Teubner, 1959).
The efficiency of foliar fertilization depends on nutrient mobility within a plant. Nutrient absorption mechanism by the above-ground parts is crucial to optimize foliar fertilization (Pawel Wojcik, 2004). There are three ways of absorption of foliar nutrients; they are (i) penetration through the epicuticular wax and the cuticular membrane (ii) penetration through the cell wall (iii) penetration through the plasma membrane. Some factors influencing absorption of mineral nutrients are (i) environmental factors such as light and temperature, air humidity; (ii) factors related to spray solution such as solution 
concentration, $\mathrm{pH}$, surfactants, chelates and (iii) biological factors such as species and variety, leaf surface and leaf age, nutritional status and plant development stages (Alexander, 1986). Application of nutrient sprays may indeed be an environmentally friendly fertilization method since the nutrients are directly delivered to the plant in limited amounts, thereby helping to reduce the environmental impact associated with soil fertilization.

Its use is particularly widespread in horticulture and its potential in the most relevant agricultural crops is continuously increasing. Foliar sprays of nutrients is resorted when the crop is unable to absorb nutrients from soil due to non-availability of particular element; problems in translocation of that particular element; mobility factor of the nutrient element; type of soil and whether conditions existing during absorption and translocation of nutrients. Foliar nutrition becomes inevitable when any unsuitable environment including conditions of faulty mineral nutrition affects the growing plant in specific ways. A particular advantage of foliar nutrient application is that it supplies nutrients directly to the various metabolizing parts of the plant without the possibility of antagonism due to cations or deposits caused by reactions with anions. Crops like cereals are routine sprayed several times during the season for different purposes, like pesticide treatment and growth regulation. In such cases mixtures between compatible foliar fertilizer and pesticide improve fertilizer cost effectiveness and can even increase the activity of the pesticides.

\section{Importance of Foliar Mineral Nutrition}

In agriculture practices fertilizer is an important source to increase crop yields. Due to several compensations of foliar application methods like quick and proficient response to needs of plants, less needed products and soil conditions independency, the concentration towards foliar fertilizers is arising day by day. It is also determined that during crop growth supplementary foliar fertilization increase plants mineral status and improve crop yields (Kolota and Osinska, 2001). The function of nutrients is one of the chief importance in improving quality and productivity of vegetables which require mineral nutrients in large amount and continuous inorganic fertilizers consumption which results in micronutrients deficiency, disproportion in physiochemical properties of soil and low production of crops. For that reason these minerals are practiced in foliar form (Jeyathilake et al., 2006). Foliar application is most effective when roots are incapable of absorbing required amount of nutrients from soil due to some reasons like high degree of fixation, lack of soil moisture, losses from leaching and low soil temperature (Singh et al., 1970). The mineral nutrients assimilation rate by plants aerial parts is not only different among plant species but also among many different varieties of the same plant species (Wojcik, 2004). Nutrients applied to the foliage are generally absorbed more rapidly than when applied to the soil. Foliar application provides a means of quickly correcting plant nutrient deficiencies, when identified on the plant. It often provides a convenient method of applying fertilizer materials, especially those required in very small amounts and the highly soluble materials.

\section{Deficiency symptoms and foliar fertilization}

\section{Nitrogen}

When $\mathrm{N}$ is deficient, plants are much smaller than normal, leaf area especially is reduced, bud dormancy is prolonged, tillering is suppressed, lateral and apical bud production 
or expansion is decreased and flowering is delayed. Foliage becomes pale green and leaf senescence and dehiscence are accelerated. The leaves often develop strong purple, red or orange anthocyanin tints in addition to the yellow background caused by loss of chlorophyll, a principal labile nitrogenous constituent. The interveinal areas and older leaves are first to show loss of chlorophyll and appearance of supplementary pigments. Leaf base and stem of cereals become red- purple. Brassicas e.g. cauliflower show orange or red flushes on upper leaf surfaces and tomatoes show purple tinting of veins on lower leaf surfaces and on petioles. Root nodulation of legumes is generally stimulated in conditions of soil nitrogen deficiency in non-legumes also. Chlorosis in general, starts in older leaves in cereals, under field conditions if deficiency is severe whole crops appears yellowish and growth is stunted.

\section{Under deficient conditions following are the recommendations}

\begin{tabular}{|l|l|l|}
\hline Rice & $:$ & $2 \%$ DAP at $65^{\text {th }}$ and $80^{\text {th }}$ DAS \\
\hline $\begin{array}{l}\text { Pigeon pea, green gram, cowpea, } \\
\text { rice fallow black gram }\end{array}$ & $:$ & $\begin{array}{l}2 \% \text { Dap }+ \text { NAA } 40 \mathrm{ppm} \text { at } 50 \% \text { flowering and } 15 \text { days } \\
\text { after. }\end{array}$ \\
\hline Cotton & $: \begin{array}{l}1 \% \text { urea spray at square initiation, flower initiation and } \\
\text { peak boll formation. }\end{array}$ \\
\hline Fruit crop & $:$ & $0.5-1 \mathrm{~kg}$ urea/100 lit.- before and after bloom. \\
\hline
\end{tabular}

\section{Phosphorus}

Effect of phosphorus deficiency often resembles those of nitrogen including diminutive or spindly habit, acute leaf angles, suppression of tillering, prolonged dormancy, early senescence, decreased size and number of flowers and buds. However, leaf angles become obtuse in tomato and leaves curl downwards. Foliage is usually lusterless and leaf colour changes but may be paler or darker than normal. Deep purple tints appear as in maize and tomato, or red and purple tints as in barley and several brassicas. Pigmentation is generally absent from wheat, sugar beet and potatoes. Bronze tints and necrosis of interveinal or marginal areas of older leaves appear in potatoes, french beans and red clover (Greenwood and Djokoto, 1952), intense purpling in maize, peas and other plants (Hewitt et al., 1954). Phosphorus deficiency in potato resembles some effects of late "Blight" by Phytophthora infestans and growth is stunted. Purple orange coloured older leaves. In cereals, tillering is drastically reduced.

Under conditions where a quick $\mathrm{P}$ absorptions is required the rate recommended is $1.5-2.5$ $\mathrm{kg}$ of $\left(\mathrm{NH}_{4}\right)_{2} \mathrm{HPO}_{4},\left(\mathrm{NH}_{4}\right)_{2} \mathrm{SO}_{4}$ in 400 lit. of water. The recommended concentration of (NH4)2 HPO4 can be used for various crops at various stages as follows.

\begin{tabular}{|l|c|l|}
\hline Rice & $:$ & When panicle and main stem are 50\% flowered. \\
\hline Wheat & $:$ & When anthesis is complete. \\
\hline Maize & $:$ & At 5-7 leaf stage. \\
\hline Cotton & $:$ & At square initiation, flower initiation and at peak boll formation stages. \\
\hline Soybean & $:$ & At flowering and pod filing stages. \\
\hline Grape vine & $:$ & Before fruit setting and colouring. \\
\hline Potato & $:$ & At stalk elongation phase. \\
\hline
\end{tabular}




\section{Potassium}

Potassium deficiency causes shortening of stem internodes. Plants with a crown of leaves, e.g. beet and carrot produce a rosette habit. Strong light intensity accentuates and weak light often diminishes or eliminates these symptoms. Apical dominance of the viable terminal bud is sometimes suppressed as in flax, and cereals especially barley, which develop excessive basal shoots or tillers, or in citrus species which produce side shoots along the length of principal branches. Very severe deficiency causes death of the terminal bud with typical "dieback" effects.

Leaf scorch, usually preceded by irregular marginal or interveinal Chlorosis, almost always occur and appears first in oldest leaves which often curve downwards or become convex on the upper surface. Scorching may be pale brown, to almost black. Potato leaves develop profuse almost black necrotic spotting first on the lower leaf surfaces and this breakdown is associated with excessive tyrosinase activity (Mulder, 1949). In tomatoes the oldest three or four leaves may remain free of scorching for several days after mid-stem leaves are affected.

In clover and lucerne necrotic spotting between the radiating veins produces a regular and characteristic pattern. Scorching is sometimes preceded or followed by pronounced red or violet probably anthocyanin pigment formation (Millikan, 1953). In potassium deficient barley profuse bleached necrotic lesions are associated with excessive concentration of putrescine (Richards and Coleman, 1952). Putrescine also accumulates in wheat and clovers and other plants (Smith and Richards, 1962; Smith, 1963). Scorching may be caused by local dehydration. Petioles may develop necrotic lesions or collapsed water-soaked areas as in celery.

For correcting deficiency of $\mathrm{K}$ or alleviating $\mathrm{K}$ related constraints, recommended rate of 3$5 \mathrm{~kg}$ of $\mathrm{KNO}_{3}, \mathrm{~K}_{2} \mathrm{SO}_{4}, \mathrm{KCL}$ (MOP) per 400 litres of water is sprayed as follows:

\begin{tabular}{|l|c|l|}
\hline Rice & $:$ & When panicle, internode and main stem elongated to $15 \mathrm{~cm}$. \\
\hline Wheat & $:$ & At flowering. \\
\hline Soybean & $:$ & At flowering and pod filing stages. \\
\hline Potato & $:$ & Stalk elongation phase. \\
\hline Fruits & $:$ & $0.54 \mathrm{~kg} \mathrm{KNO}_{3} / 100$ lit on $2^{\text {nd }}, 4^{\text {th }}$ and $6^{\text {th }}$ week after sowing. \\
\hline
\end{tabular}

\section{Calcium}

In many broad leaved plants, especially brassicas, the earliest symptoms may be paling of the leaf margins some distance behind the apex. Successively younger leaves become more acutely affected nearer the apex as in spinach and beet. Finally only the blackened or shriveled leaf midrib remains. Similar characteristic symptoms occur in tobacco (McMurtrey, 1941). Central areas of partly expanded leaves of kale and cauliflower become grey tinted and then necrotic in a clearly defined area within the margins. In cereals e.g. barley, the emerging young leaves remain trapped in subtending leaves as in copper deficiency also. Leaves which have emerged remain rolled, chlorotic and may have circular constructions a few centimeters behind the apex as in rice (Olsen, 1958) or barley. The distal portion wilts and withers. Cereals are generally less susceptible than broad-leaved plants. In rubber, leaf margins and tips of younger leaves become abruptly bleached and scorched (Shorrocks, 1964). Calcium deficiency in potatoes 
produces malformed, miniature and very numerous tubers. Sprouted tubers growing in severely calcium deficient conditions produce roots but the shoots die back producing the condition of sub-apical necrosis (Wallace and Hewitt, 1948). Roots are often damaged by calcium deficiency when very severe. Root tips become translucent or gelatinous and swollen; apical growth ceases, lateral primordial proliferate and die-back. Root nodulation of legumes is inhibited.

Foliar spray with $0.75 \%$ to $1 \%$ calcium nitrate solution is recommended for $\mathrm{Ca}$ deficient crops. Calcium nitrate sprays should not be used on cultivars that are sensitive to nitrate injury (Stiles et al, 1983). The general choice for $\mathrm{Ca}$ sprays is $\mathrm{CaCl}_{2} . \mathrm{CaCl}_{2}$ cannot combined with boron solutions. High $\mathrm{pH}$ may be one of the reasons for occasional leaf injury caused concentrated sprays of $\mathrm{CaCl}_{2}$ (Yong et al, 1983). In apples related to physiological disorders, recommended stages are 3, 5, 7 and 9 weeks before harvest. In tomato for correction of blossom end rot, the stages are bud formation of the first cluster, the beginning of flowering in the first cluster and at fruitlet stage.

\section{Magnesium}

Chlorosis usually appears first in oldest leaves and is progressive but occasionally as in tomatoes the first leaves may be less sensitive than second or third leaves. In several species the Chlorosis which is generally interveinal occurs within a persistent green margin of the leaves. Oat leaves show characteristics parallel 'beading' of orange and pale green areas along the interveinal areas (Hewitt, 1953). The principal distinction is that magnesium deficiency appears in the older (first) leaves but manganese deficiency tends to appear in younger leaves of the plant. The spotted areas rapidly become necrotic and coalesce into larger scorched areas. The leaflets become generally bright pale green or yellow green and then totally bleached. Nonavailability of $\mathrm{Mg}$ in most of the cotton growing areas results in "Red Leaf Disease".

In cotton, which reddening of leaf occurs, foliar spray of $\mathrm{MgSO}_{4} 5 \%$, urea $1 \%$ and $\mathrm{ZnSO}_{4} 1 \%$ on 50 and $80^{\text {th }}$ DAS is recommended to correct this malady caused by magnesium deficiency. For correcting $\mathrm{Mg}$ deficiency in fruit trees, 2 to 5 sprays with $2 \%$ Epsom salts are recommended, the first spray should be applied at June and the next spray at 2 weeks intervals. Foliar applications of $\mathrm{MgCl}_{2}$ is employed. In potatoes bud formation or flowering is the recommended stage. In apple, $1^{\text {st }}$ application is done at balloon stage and spray is repeated 3-4 times at 15 days interval. In grapevine to prevent grape stalk necrosis, the berry formation and beginning of berry ripening are suitable stages for foliar spray.

\section{Iron}

Deficiency symptoms appear first as Chlorosis of young rapidly expanding leaves. Chlorosis is characteristically interveinal and produces contrasting "tramline" effects in parallel-veined species, e.g. in cereals and grasses and shown very well in maize; leaves may become uniformly chlorotic without collapsing. Glumes of oats may be more chlorotic than the flag leaf. In many broadleaved plants e.g. tomato, beets, spinach, apple and brassicas, the fine reticulate pattern of darker green veins and pale yellow-green to ivory tinted chlorosis in interveinal patches are usually easily recognizable. In the final stages the veins are also totally chlorotic and may then collapse. In the cereals, especially wheat, barley and oats, bleached or brown lesions develop more frequently in the interveinal areas and leaves collapse transversely. This behavior is sometimes easily confused with effects of manganese 
deficiency. In some broad-leaved plants young leaves are often generally uniformly chlorotic as in green pepper but basal areas tend to become chlorotic first as in tomato and spinach leaves. For the correction of iron deficiency following are the recommendations.

\begin{tabular}{|l|l|l|}
\hline Rice & $:$ & 2 to 3 foliar sprays of 1-2\% $\mathrm{FeSO}_{4}$ at weekly intervals \\
\hline Sorghum & $:$ & $\begin{array}{l}1 \% \mathrm{FeSO}_{4} \text { spray at } 25 \text { days after planting and is repeated } \\
15 \text { days after first spray. }\end{array}$ \\
\hline Groundnut, chickpea and soybean & $:$ & 3 sprays of $2 \% \mathrm{FeSO}_{4}$ at 15 days interval. \\
\hline Lemon & $:$ & $0.5 \% \mathrm{FeSO}_{4}$ spray at new flush, flowering and fruiting. \\
\hline Apple and pear & $:$ & $\begin{array}{l}4-5 \text { foliar sprays of } 0.1 \% \mathrm{Fe}-\mathrm{EDTA} \text { at } 15 \text { days interval } \\
\text { from petal fall. }\end{array}$ \\
\hline Vegetables & $: \begin{array}{l}\text { Two sprays of } 0.05 \% \mathrm{Fe}-\mathrm{EDTA} \text { in } 15 \text { days interval when } \\
\text { deficiency occurs. }\end{array}$ \\
\hline
\end{tabular}

\section{Copper}

Disorders caused by copper deficiency include "exanthema" and in citrus, apple and pear where the name "summer dieback" is applied. In fruit trees, the bark becomes rough with raised blisters and deep splits which often exude gum; brown stains appear in the bark. Shoot tips die back and multiple abortive auxillary shoots often develop with diminutive leaves in citrus, stone fruit and rubber. Abnormal 'water-shoots' extend rapidly in apple and extension of the numerous buds produces a 'witches broom' habit.

In many plants the young leaves are most severely affected as in cereals, several legumes, tomato, flax etc. leaves are often rolled or curled. White, tightly rolled emerging leaves are especially characteristic in wheat and oats, and the rolled leaves are sometime coiled in a spiral (spring-like) which may reverse the direction along its length. The emerging leaves may be trapped in a loop in the subtending leaf (Hewitt and Jones, 1951). These symptoms are known as 'white-tip' or 'reclamation disease' found on peaty soils. Interveinal crinkling and marginal wilting of young leaves occurred in green pepper and tomato (Hewitt and Watson, 1980). In citrus and oranges, two foliar sprays of $0.4-0.5 \% \mathrm{CuSO}_{4}$ in a year at the emergence of new growth and in oil palm, foliar spray of $0.08 \% \mathrm{CuSO}_{4}$ at monthly intervals is recommended.

\section{Zinc}

Zinc deficiency produces leaf malformation, often a characteristic irregular mottling with yellow-ivory interveinal areas and extreme resetting of terminal and lateral shoots in woody species and multiple branching. Several well-known disorders include 'little leaf' of apple, 'mottle leaf', 'frenching' of citrus, 'sickle leaf' of cocoa, 'yellows' of walnut. Zinc deficiency is common in several annual and other non-woody species and caused "white bud" in maize and resetting in cotton. Rice, tobacco, green pepper and tomato are also quite sensitive and leaf malformation is common, with wavy margins or epinasty and curling of lamina and scorching.

For the correction of zinc deficiency, following are the recommendations. 


\begin{tabular}{|l|l|l|}
\hline Rice and maize & $:$ & $0.5 \% \mathrm{ZnSO}_{4}$ at 30,45 and 65 days after transplanting. \\
\hline Sugarcane & $:$ & $2-3$ sprays of $0.5 \% \mathrm{ZnSO}_{4}$ \\
\hline Grapes & $:$ & $0.5 \% \mathrm{ZnSO}_{4}$ at full bloom. \\
\hline Citrus & $:$ & $2-3$ sprays of $0.5 \% \mathrm{ZnSO}_{4}$ before flowering. \\
\hline Tea & $:$ & 5 foliar sprays of $0.5 \% \mathrm{ZnSO}_{4}$ after pruning. \\
\hline
\end{tabular}

\section{Boron}

Disorders caused by boron deficiency include "stem crack" of celery narrow stem in cauliflower, "heart rot" of sugar beet, "water core" of turnip, "top sickness" of tobacco, 'yellows' of alfalfa. 'corky core' of apple fruit, 'hen and chickens' of grapes. The typical symptoms of boron deficiency in cereals include the development of abnormally thick stems, the death of growing points and the formation of distorted and unperfect heads. Floral and fruiting organs are especially sensitive to boron deficiency.

The correction measures for boron deficiency are as follows:

\begin{tabular}{|l|l|l|}
\hline Groundnut & $:$ & $1 \%$ boric acid at flowering and pegging. \\
\hline Citrus & $:$ & 3 foliar sprays of $0.1 \%$ boric acid at new flesh, flowering and fruiting stage. \\
\hline Grapes & $:$ & $0.2 \%$ boric acid spray at full bloom. \\
\hline $\begin{array}{l}\text { Guava and } \\
\text { Mango }\end{array}$ & $:$ & $0.4 \%$ borax before flowering. \\
\hline $\begin{array}{l}\text { Cabbage and } \\
\text { Cauliflower }\end{array}$ & $:$ & $0.3 \%$ boric acid at 15 days after planting and 15 days prior to heading. \\
\hline Potato & $:$ & $0.2 \%$ Borax at 4,6 and 9 weeks after planting. \\
\hline
\end{tabular}

\section{Manganese}

Manganese deficiency produces a great variety of symptoms although chlorosis in some form is usually seen. Several well known field disorders are caused by manganese deficiency including 'marsh spot' of beet. Manganese deficiency in leaves is distinguishable from iron deficiency by the appearance of varied but characteristic necrotic spotting or lesions. In tomato, the necrosis appears as small brown or orangetinted necrotic spots causing speckling close to major veins and along mid-ribs.

For alleviating the constraints related to manganese deficiency, following are the recommendations.

\begin{tabular}{|l|l|l|}
\hline Rice & $:$ & $2-3$ foliar sprays of $1 \% \mathrm{MnSO}_{4}$ at important growth stages. \\
\hline Wheat and barley & $:$ & $0.5-1 \% \mathrm{MnSO}_{4}$ at 30 and 60 days after sowing. \\
\hline Groundnut & $:$ & $\begin{array}{l}3 \text { foliar sprays of } 0.5 \% \mathrm{MnSO}_{4} \text { at early growth, flowering and } \\
\text { pegging. }\end{array}$ \\
\hline Soybean & $:$ & $\begin{array}{l}2-3 \text { sprays of } 0.3 \% \mathrm{MnSO}_{4} \text { or } 0.1 \% \mathrm{Mn} \text { EDTA at early bloom and } \\
\text { early pod setting. }\end{array}$ \\
\hline Lemon and oranges & $:$ & 3 sprays of $0.2-0.3 \% \mathrm{MnSO}_{4}$ at new growth, flowering and fruiting. \\
\hline Onion & $:$ & $\begin{array}{l}2-3 \text { sprays of } 0.3 \% \mathrm{MnSO}_{4} \text { at } 40-50 \text { days after planting in } 15 \text { days } \\
\text { interval. }\end{array}$ \\
\hline
\end{tabular}




\section{Molybdenum}

Molybdenum deficiency causes 'whip tail' in cauliflower. This deficiency is predominant in acidic soils. Deficient leaves turn greenish yellow. The tip of leaves get elongated and looks like tail. In cauliflower, foliar spray of $0.5 \%$ sodium molybdate at 15 days after planting is recommended. In peas and soybean, foliar spray of $0.1 \%$ sodium molybdate, when plants are of about $10 \mathrm{~cm}$ height. In maize, foliar spray of $0.1 \%$ sodium molybdate at 60 days after sowing.

The correction measures are as follows,

\begin{tabular}{|l|l|l|}
\hline Cauliflower & $:$ & $0.5 \%$ sodium molybdate at 15 days after planting. \\
\hline Peas and soybean & $:$ & $0.1 \%$ sodium molybdate when plants are of about $10 \mathrm{~cm}$ height. \\
\hline Maize & $:$ & Foliar spray of $0.1 \%$ sodium molybdate at 60 days after sowing. \\
\hline
\end{tabular}

Tolerance of plant foliage to mineral nutrient sprays

\begin{tabular}{|l|l|l|}
\hline Nutrient & Formulation or salt & Kg per 400 lit. of water \\
\hline \multirow{5}{*}{ Nitrogen } & Urea & $3-5$ \\
\cline { 2 - 3 } & $\begin{array}{l}\mathrm{NH}_{4} \mathrm{NO}_{3}, \\
\left(\mathrm{NH}_{4}\right)_{2} \mathrm{HPO}_{4}, \\
(\mathrm{NH} 4)_{2} \mathrm{SO}_{4}\end{array}$ & $2-3$ \\
\cline { 2 - 3 } & $\mathrm{NH}_{4} \mathrm{Cl}, \mathrm{NH}_{4} \mathrm{H}_{2} \mathrm{PO}_{4}$ & $2-3$ \\
\hline Phosphorus & $\begin{array}{l}\mathrm{H}_{3} \mathrm{PO}_{4}, \text { others see } \mathrm{N} \\
\text { above }\end{array}$ & $1.5-2.5$ \\
\hline Potassium & $\mathrm{KNO}_{3}, \mathrm{~K}_{2} \mathrm{SO}_{4}, \mathrm{KCl}$ & $3-5$ \\
\hline Calcium & $\mathrm{CaCl}_{2}, \mathrm{Ca}\left(\mathrm{NO}_{3}\right)_{2}$ & $3-6$ \\
\hline Magnesium & $\mathrm{MgSO}_{4}, \mathrm{Mg}\left(\mathrm{NO}_{3}\right)_{2}$ & $3-12$ \\
\hline Iron & $\mathrm{FeSO}_{4}$ & $2-12$ \\
\hline Manganese & $\mathrm{MnSO}_{4}$ & $2-3$ \\
\hline Zinc & $\mathrm{ZnSO}_{4}$ & $1.5-2.5$ \\
\hline Boron & Sodium borate & $0.25-1$ \\
\hline Molybdenum & Sodium molybdate & $0.1-0.15$ \\
\hline
\end{tabular}

\section{Proper timing of foliar applications}

\section{Proper growth stage}

This is one of the most critical aspects of a foliar feeding programme. Foliar applications should be timed to provide needed nutrients during the yield potential determining time frame of plant development, which will in turn favourably influence the post reproductive and development stages. Multiple, low rate applications may show the most favourable responses within these time frames whether a crop is nutritionally sound or not. Careful crop growth stage monitoring on a weekly and sometimes a daily basis, is essential.

A comprehensive planttissue analysis programme taken just prior to the desired application is also essential to establish levels of plant nutrients most limiting to crop growth. DRIS (Diagnosis and Recommendation Integrated System) analysis of tissue tests is the best method of relating tissue nutrient levels to desired plant needs by ranking plant nutrients in order of most limiting to least limiting. 


\section{Proper crop condition}

Generally speaking, crops that are nutritionally sound will be most likely to respond to foliar feeding. This is due to better tissue quality (allowing for maximum absorption of nutrients into leaf and stem) and better growth vigour (allowing for translocatable nutrients to be rapidly moved to the rest of the plant). Crops under heat or moisture stress show less response to foliar applications due to lower leaf and stem absorption rates and/or poor vigour. However, foliar feeding does benefit crop performance and yield if an application was made prior to heat or moisture stress. Recovery from cold growing conditions and herbicide stress can be hastened with proper foliar applications. Good recovery of corn suffering from light to moderate hail damage has been shown where nitrogen-sulfur solutions were foliar applied. Under most conditions, however, due to the practical and economic limitations on the amount of nutrients that can be foliar applied to give a favourable growth response, foliar feeding has a limited rescue capability.

\section{Proper meteorological conditions}

Environmental influences, such as time of day, temperature, humidity and windspeed influence the physical and biological aspects of foliar applications. Plant tissue permeability is an important factor in absorption of nutrients into the plant: warm, moist and calm conditions favour highest tissue permeability, conditions found most often in the late evening hours, and occasionally in the early morning hours.

In conclusion, in respect of the above review it can be concluded and suggested that the foliar plant mineral nutrients foliar application of nutrients improves the growth and quality of the crop. This method of application should be considered as a temporary measure that supplements soil application. The advantages of foliar fertilization are high effectiveness, rapid plant responses and elimination or reduction of toxicity symptoms brought about by excessive soil accumulation of the elements. The disadvantage of foliar nutrition is that the effects of sprays are temporary. Foliar fertilization is the best form of fertilization. But for this to come true in practice, further research and development work are still needed in areas like, penetration and translocation conditions and criteria, interaction between different elements, degree and way of efficiency of carrier substances, application of higher amounts of macroelements to the foliage without causing foliage burn, mixability and effectiveness of foliar nutrients applied as concentration in low volume applications, interaction between foliar fertilizers and pesticides and optimum timing of foliar nutrient sprays.

\section{References}

Alexander, A. 1986. Optimum timing for foliar nutrient sprays. In: Alexander, A. (Ed.), Foliar Fertilization. Kluwer Acad. Publishers, Dordrecht, The Netherlands. Pp. 44-60.

Beyers, E., and J.H. Terblanche. 1971. Identification and control of trace element deficiencies. III copper deficiency. Decid. Fruit grower 21:192202.

Chamei, A. 1980. Physiol. Veg. 18: 313-323.

Greenwood, M. and Djokoto, R.K. 1952. Symptoms of mineral deficiency in cocoa. J. Hort. Sci. 27: 223-236.

Hewitt, E.J. 1953. A biological approach to the problems of soil acidity.In. Soc. Soil Sci. Commun.II\& IV Dubhn, 1952. Trans. 1: 107-118.

Hewitt, E.J., E.W. Bolle-Jones, and P. Milles, 1954. The production of copper, zinc and molybdenum deficiencies in crop plants grown in sand culture with 
special reference to some effects of water supply and seed reserves. Pl. Soil, 5: 205-222.

Jeyathilake, P.K.S., I.P. Reddy, D. Srihari and K.R. Reddy, 2006. Productivity and soil fertility status as influenced integrated use of $\mathrm{N}$-fixing Biofertilizers, organic manures and inorganic fertilizers in onion. Journal of Agricultural Sciences, 2(1): 46-58.

Jyung, W.H. and S.H. Wittwer. 1965. Pathways and mechanism for foliar absorption of mineral nutrients Agri. Sci. Rev. 3: 26-36.

Kolota, E. and M. Osinska, 2001. Efficiency of foliar nutrition of field vegetables grown at different nitrogen rates. In: Proc. IC Environ. Probl. N-Fert. Acta Hort., 563: 87-91.

Life Sciencees.Cornell University. Ithaca and N.Y. State Agr. Exp. Sta. Geneva.

Milikan.C.R. 1953.Nutritional disorders in subterranean clover. Tech. Bull. Dep. Agric. Vict. 11, 39 PP.

Mulder, E.G. 1949.Mineral nutrition in relation to the biochemistry and physiology of potatoes.I. Pl. Soil. 2: 59121.

Natesan. S. 1995. In: "Compendium on multimicronutrient fertilizers in India". Indian microfertilizer Manufactures Association, Pune.

Olsen, K.L. 1958. Mineral deficiency symptoms in rice. Bull. Arkans. Agric. Exp. 605.

Pawel Wojcik. 2004. Uptake of Mineral Nutrients from Foliar Fertilization. J. Fruit and Ornamental Plant Res., 12:
96-100.

Pissarek, W.P. 1979. Z Acker- Pflanzenban. 148: 62-71.

Shorrocks, V.M. 1964. Mineral deficiencies in Hevea and associated cover plants.Kualalumpur.Rubb. Res. Inst.

Singh, C., R.C. Joshi and C.V. Katti, 1970. Soil and foliar application of nitrogen to rain fed cotton. Indian Journal of Agronomy, 15: 269-271.

Smitha, T.A. 1963. L-arginine carboxylase of higher plants and its relation to potassium nutrition. Phyto Chemistry 2: 241-252.

Stiles, W.C., T.J. Burs.And H. Riedl. 1983. Cornell recommendations for commercial tree fruit production. N.Y. State College of Agrl.and Life Sciencees.Cornell University.Ithaca and N.Y. State Agr. Exp. Sta. Geneva.

Wallace, T. and Hewitt, E.J. 1948.Effects of calcium deficiency on potato sets in acid soils. Nature Lond.161:28.

Wallace, T. and Hewitt, E.J. 1948.Effects of calcium deficiency on potato sets in acid soils. Nature Lond.161:28.

Wittwer, S.H. and F.G. Teubner. 1959. Foliar absorption of mineral nutrients. Annu. Rev. Plant Physiol. 10: 13-27.

Wojcik, P., 2004.Uptake of mineral nutrients from foliar fertilization. J. Fruit Orn. Plant Res. Spec. ed. 12: 201-218

Young, R.S., T.L. Auxt, G. Bassat, H.W. Hog mire and J.F. Hottz. 1983. West Virginia spray bulletin for commercial tree fruit growers. Cir. 436. West Va. Univ. Coop. Ext. Serv.

\section{How to cite this article:}

Rajasekar, M., D. Udhaya Nandhini and Suganthi S. 2017. Supplementation of Mineral Nutrients through Foliar Spray - A Review. Int.J.Curr.Microbiol.App.Sci. 6(3): 2504-2513. doi: https://doi.org/10.20546/ijcmas.2017.603.283 